\title{
MODIFICATIONS IN THE SUGAR INDUSTRY TO INCREASE THE ELECTRICITY GENERATION
}

\author{
Pankaj Kumar Agrahari ${ }^{1}$, Ravi Kumar Gupta ${ }^{2}$ \\ ${ }^{1}$ Assistant Prof, Department of Mechanical Engineering Ambalika Institute of Management \& Technology, Lucknow \\ ${ }^{2}$ Department of Mechanical Engineering, KNIT Sultanpur - 228118 (UP)
}

\begin{abstract}
Sugar Industry is one of the major agro based industry of India and sugar cane is one of the important cash crop. In sugar industry besides sugar crystal, ethanol and electricity are also produced. The sugar cane industry has enormous potential to produce energy by using its byproducts as bagasse (the fibrous residue of cane milling) and trashes (the cane tops and leaves). It has been seen that the electricity generation is generally very less in most of the sugar cane industries as compared to their respective capacity. In view of this it is essential to study about the electricity generation and the factors affecting it. In this regard the Kisan Sahkari Chini Mills Ltd Sultanpur (U.P) has been selected for investigation for the above purpose. This investigation also aims to propose the modification or improvement in the existing technology for more electricity generation. The technology presently used for electricity generation in this sugar industry is Condensing Extraction Steam Turbine (CEST) technique. From the past experience it is observed that CEST technology is not commercial viable. Because in CEST technique, two turbines are used mill turbine and power turbine. Mill turbine is used to transmit motion to the crusher and power turbine is used for the generation of electricity. The efficiency of mill turbine is very less (about 25-30\%) as compared to power turbine (about 65-70\%). It has been reported that to increase the power output of sugar industry, two modifications should be performed. First modification is the use of biomass integrated gasifier and the second one is the use of DC motor in place of mill turbine. Biomass integrated gasifier increases the electricity generation and use of DC motor reduces the steam consumption which finally increases the power output. By using above two modifications in the CEST technique, the emission of CO2, greenhouse gases and particulates would also be significantly reduced. The significant level of biomass available as byproducts of sugar cane processing, offers a potentially attractive application of gasifier in sugar industry. With the use of above two modification in the CEST technique in sugar factroies, selling additional power to the grid will be possible. This also offers an excellent opportunity for the sugar mills to generate additional revenue.
\end{abstract}

\section{INTRODUCTION}

The cane sugar industry has long recognized the enormous potential in the use of bagasse for the production of energy. Many sugar factories are presently producing considerable amounts of electricity for export to the utility grid while at the same time meeting on-site energy needs.For the production of electricity; there are methods which are not fulfilling the present demand of electricity and also not viable environmentally [1]. One of the methods which have been widely used is Condensing Extraction Steam Turbine (CEST).To meet the present demand, first of all analyzed the drawbacks of CEST technique and find a new technology; Biomass integrated gasifier technique. BIG technology is an advance technology with the potential to be cost-competitive with conventional CEST; using biomass by-products of sugarcane processing as fuel; while dramatically increasing the electricity generated per unit of sugarcane processed [1].Biomass gasification technology applied to bagasse gasification in conjunction with gas fired turbines, offers higher thermodynamic efficiency. In the biomass integrated gasifier technique there is not only increments in efficiency but also improvements in acceptability.Integrated Biomass Gasification Combined Cycle systems replace the traditional combustor with a gasifier and gas turbine. Exhaust heat from the gas turbine is used to produce steam for a conventional steam turbine. The gas and steam turbines operate together as a combined cycle [2].

\section{LITERATURE REVIEW}

During the past decade, there have been substantial efforts undertaken worldwide to develop CEST technology [3]. A comprehensive research work has been published by Southern Bahia, Brazil and Selby, North Yorkshire, UK. By the different research work, there is gradual advancement in technology as BIG open cycle and BIG combined cycle. In Mauritian sugar industry, while adopting the conventional steam cycle, supplied on an average $15 \mathrm{kWh} / \mathrm{t}$ cane (Anon, 1992-95) electrical energy to the national grid (based on total cane production), totaling $70-85 \mathrm{GWh}$ annually. In $1997 ; 125 \mathrm{GWh}$ of electricity was exported to the national grid [1]. With biomass gasification technology, efficiencies in the range of $40-45 \%$ based on net plant output and lower heating value of the fuel are reported (Elliot and Booth, 1995) to be feasible evenwith first generation plants. Further, it appears that plant size will have little effect on the economic and technical viability of BIG [1]. Efforts have been made over the past 15 years to develop the capability for recovering and using trash as a fuel for electricity generation in a number of countries, Including Australia [4]. 


\section{CONDENSING EXTRACTION STEAM TURBINE (CEST) TECHNIQUE}

1. In sugar Industry CEST technique is used for electricity production at present.

2. Figure 1 shows the layout of CEST technology in Kisan Sahkari Chini Mills Ltd, Sultanpur. The components used in the CEST technique are: mill house, bagasse vessel, furnace, boiler, steam turbine, generator, mill turbine.

3. In this technique bagasse which is obtained from sugarcane milling carried to bagasse vessel through rake elevator.

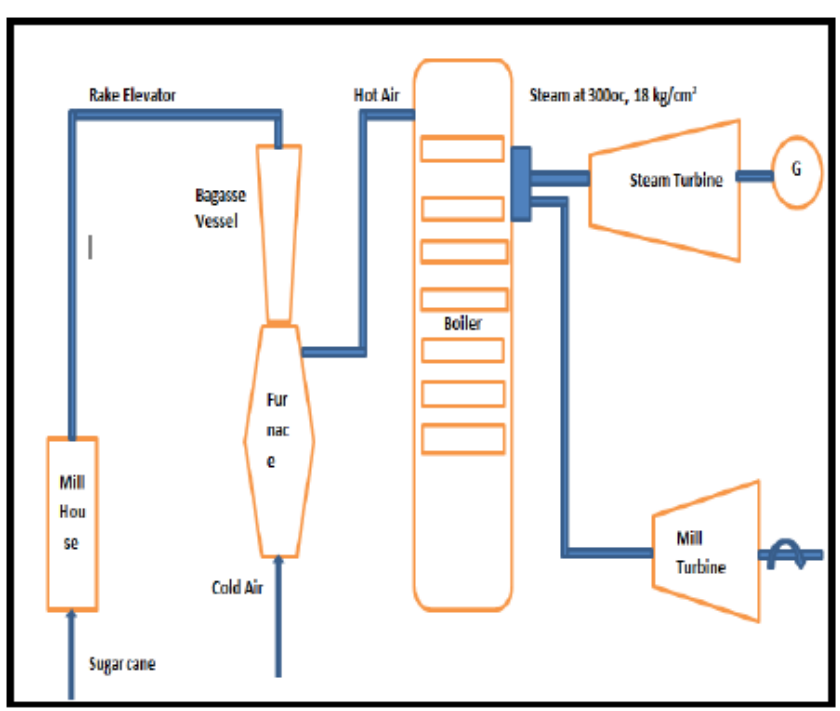

Fig 1 Schematic diagrams for a Condensing Extraction Steam Turbine (CEST) in Kisan Sahkari Chini Mills Ltd,Sultanpur

4. This bagasse is supplied to furnace to heat the cold air which is inducted through force draft fan.

5. Hot air from the furnace is used to produce steam in the boiler.

6. The steam generated from the boiler is used in power turbine and mill turbine both.

7. The steam from boiler is supplied to steam turbine as well as mill turbine. The mechanical energy from steam turbine is transmitted to generator. The mill turbine is used to rotate the rollers for crushing.

\section{BAGASSE HANDLING}

First of all sugarcane from the unloading department goes to cutter after that it goes to leveler to cut the cane into smaller length. After the leveler cane goes to crushing department where cane juice and bagasse is separated. From here bagasse is supplied to boiler unit where it produces steam. And excess bagasse is kept for any unplanned events.

\section{MODIFICATIONS IN CEST TECHNIQUE TO INCREASE THE POWER OUTPUT}

By improvements of the CEST plant in sugar factroies, selling additional power to the grid will be possible. This also offers an excellent opportunity for the sugar mills to generate additional revenue. This also contributes to serve the national cause in a small way, by bridging the demand supply gap. To increase the power in the sugar factory there are two methods, first one is to replace high power consuming equipment with that type of equipment which consumes less power and second method is to increase the power output of the sugarmill. To increase the power output in sugar mill one of the methods is to replace mill turbine with DC motors and second method is use of Biomass Intregrated Gasifier.

\subsection{Replacement of Mill Turbine with DC Motors}

In CEST technique Steam turbines are used to drive the mill. One of the methods of increasing the power output, is to replace the lower efficiency mill turbine with better efficiency drives as DC motors.Mill turbine has efficiency of $25-30 \%$. And power turbine has efficiency of $65-$ $70 \%$.Hence, The steam saved by the installation of DC motors can be passed through the power turbine to generate additional power.

\subsection{Biomass Integrated Gasifier (BIG) Technique}

1. Figure 2 shows the layout of BIG technology; the components used in the BIG are- Bagasse trash vessel, dryer, gasifier, gas cleaning System, gas turbine, generator, heat recovery steam generator.

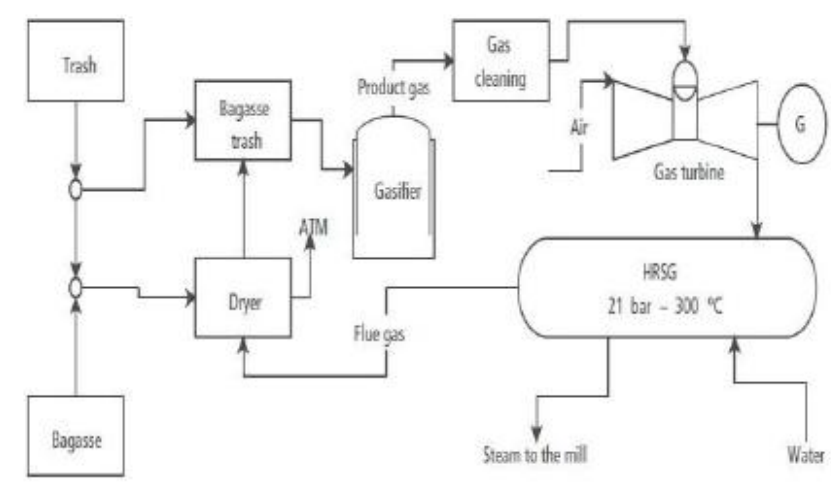

Fig 2 Simplified diagram of BIG plant integrated with the mill

2. And exhaust gases after heat recovery steam turbine flows to dryer to reduce the moisture level of bagasse.

3. Biomass integrated Gasifier Technique uses the combined cycle format with a gas turbine driven by gases from the gasifier.

4. In this technique bagasse which is obtained from sugarcane milling carried to bagasse and trash vessel. This bagasse and trash are supplied to gasifier to produce product gas.

5. The product gas which is obtained from gasifier is passed through gas cleaning system. The gas after adequate cleaning is burned in a combustion chamber (associated with gas turbine) comes out to be as hot flue gas.

6. This hot flue gas is supplied to gas turbine where it produces electricity with the help of generator. 
7. After expansion in gas turbine exhaust gas exchanged heat with water to generate steam at 21 bar and $300 \circ \mathrm{o}$. The expansion of this steam takes place in steam turbine; subsequently produces electricity through steam recovery steam generator.

8. After expansion in steam turbine, exhaust steam may be circulated by condenser or used as process steam for the manufacturing of sugar.

\section{COMPARATIVE STUDY OF CEST} TECHNIQUE AND BIG TECHNIQUE (AFTER THE MODIFICATION OF CEST TECHNIQUE)

\subsection{Electricity Production}

1. In BIG technique electricity is produced from gas and steams both - first from the gas turbine and second from the steam turbine while in the CEST technique electricity is produced only by steam turbine.

2. Thus electricity produced from BIG is more with respect to CEST technique $[3,5]$.

3. Biomass integrated gasifier increases the electricity generation and use of DC motor reduces the steam consumption which finally increases the power output.

\subsection{A Clean Environment}

1. BIG can meet all future environmental permitting constraints for thegeneration of electricity.

2. In BIG system, emission of $\mathrm{NOx}$ and $\mathrm{CO} 2$ is greatly reduced due to use of gasifier.

3. In the CEST system direct burning of bagasse and trash produces more NOxand $\mathrm{CO} 2$.

4. This environmental performance creates a wide space for the acceptability of BIG technique [6].

\subsection{Fuel Flexibility}

1. The combined cycle method of BIG technique can be fuled by natural gas, oil or coal and other agro based product in case of any unplanned events or in off season

2. While In CEST technique fuel flexibility is much less than BIG [6].

\subsection{Low Water Use}

The water required to operate the BIG plant is only 50 to $70 \%$ of the quantity required in CEST plant [6].

\subsection{Useable By- Products}

1. Waste disposal is minimal at a BIG plant.

2. The by- products which is obtained from gasifier can be used for agriculture.

3. But in CEST, burning produces ash which is lesser affective fertilizer than BIG by-products.

\subsection{Public Acceptability}

BIG sites offer an acceptable electric power generation option to a public concerned about environmental hazards and waste.Negligible plant emissions, little or no waste, safe jobs for workers, safe environments for their families, lowcost electricity for their homes are factors that result in acceptance by the general public [6].

\section{ELECTRICITY GENERATION IN KISAN SAHKARI CHINI MILLS LTD. SULTANPUR}

In Kisan Sahkari Chini Mills Ltd. Sultanpur, CEST technology is being used for electricity generation. The electricity generated in the plant is totally consumed inside the plant. If CEST technology is replaced by BIG technique, the can be considerably increased and the plant can be able to supply the electricity to the grid resulting in increased profit / revenue of the above plant. On the basis of the data available in the literature and in the plant such as electricity production, clean environment, fuel flexibility, water use and public acceptability, it can be proposed that the CEST technology being used in this plant can be replaced by BIG technique.

\section{SUMMARY AND CONCLUSION}

1. The electricity generation can be increased by using BIG technique in place of CEST technique.

2. In Kisan Sahkari Chini Mills Ltd. Sultanpur, CEST technology is being used for electricity generation. The electricity generated in the plant is totally consumed inside the plant. If CEST technology is replaced by BIG technique, this electricity generation can be considerably increased and the plant can be able to supply the electricity to the grid resulting in increased profit / revenue of the above plant.

3 . It has been reported that to increase the power output of sugar industry, two modifications should be performed. First modification is the use of biomass integrated gasifier technique and the second one is use of DC motor in place of mill turbine. Biomass integrated gasifier increases the electricity generation and DC motor reduces the steam consumption which finally increases the power output.

4. On the basis of the data available in the literature and in the plant such as electricity production, clean environment, fuel flexibility, water use, Useable by-products, Phased Construction, Coproducts and public acceptability, it can be proposed that the CEST technology being used in this plant can be replaced by BIG technique.

\section{ACKNOWLEDGEMENT}

We would like to thank the administration of KIsan Shakari Chini Mills Ltd Sultanpur for giving permission to visit and collect the data.

\section{REFERENCES}

[1] K. Kong, W Chang, A L A Wing and L W Sak Bagasse gasification technologies for electricity Production in the sugar industry, Mauritius Sugar Industry Research Institute Reduit, Mauritius.

[2] E. D. Larson and R. H. Williams, A review of biomass integrated-gasifier/gas turbine combined cycle technology and its application in sugarcane industries, with an analysis for Cuba Center for 
Energy \& Environmental Studies, Princeton University, Princeton, NJ, USA. And M. Regis L.V. Leal Centro de TecnologiaCopersucar, CP 162, Piracicaba, SP - Brazil - 13400-970.

[3] Biomass power generation Sugar cane bagasse and trash Published by: PNUD - CTC - Centro Tecnologia Canavieira Piracicaba, Brazil 2005.

[4] J. M. Ogden, S. Hochgreb and M. Hylton, Steam Economy and cogeneration in sugar cane factories, International sugar journal 1990, volume 92.

[5] V. Ensinas and S. A. Nebra, Analysis of cogeneration systems in sugar cane Factories - alternatives of steam and combined cycle Power plants Energy Department - State University of Campinas Miguel A. Lozano; Luis Serra and Mechanical Engineering Department -University of Zaragoza. Proceedings of ECOS 2006 Aghia Pelagia, Crete, GreeceJuly 12$14,2006$.

[6] H. V. Krigmont, Integrated Biomass Gasification Combined Cycle Power Generation Concept: the Gateway to a Cleaner Future, a white paper, Allied Environmental Technologies, Inc. 